\title{
Transgenic Mice Overexpressing APP and Transforming Growth Factor- $\beta 1$ Feature Cognitive and Vascular Hallmarks of Alzheimer's Disease
}

\author{
Brice Ongali, ${ }^{*}$ Nektaria Nicolakakis, ${ }^{*}$ \\ Clotilde Lecrux, ${ }^{*}$ Tahar Aboulkassim, ${ }^{*}$ \\ Pedro Rosa-Neto, ${ }^{\dagger \neq}$ Panayiota Papadopoulos, ${ }^{*}$ \\ Xin-Kang Tong, ${ }^{*}$ and Edith Hamel ${ }^{*}$ \\ From the Laboratory of Cerebrovascular Research,* and the \\ Brain Imaging Centre, ${ }^{\dagger}$ Montreal Neurological Institute, and \\ Douglas Hospital Research Centre, ${ }^{\ddagger}$ McGill University, Montréal, \\ Québec, Canada
}

High brain levels of amyloid- $\beta$ (A $\beta$ ) and transforming growth factor- $\beta 1$ (TGF- $\beta 1$ ) have been implicated in the cognitive and cerebrovascular alterations of Alzheimer's disease (AD). We sought to investigate the impact of combined increases in $A \beta$ and TGF- $\beta 1$ on cerebrovascular, neuronal, and mnemonic function using transgenic mice overproducing these peptides (A/T mice). In particular, we measured cerebrovascular reactivity, evoked cerebral blood flow and glucose uptake during brain activation, cholinergic status, and spatial memory, along with cerebrovascular fibrosis, amyloidosis, and astrogliosis, and their evolution with age. An assessment of perfusion and metabolic responses was considered timely, given ongoing efforts for their validation as AD biomarkers. Relative to wild-type littermates, $\mathrm{A} / \mathrm{T}$ mice displayed an early progressive decline in cerebrovascular dilatory ability, preserved contractility, and reduction in constitutive nitric oxide synthesis that establishes resting vessel tone. Altered levels of vasodilator-synthesizing enzymes and fibrotic proteins, resistance to antioxidant treatment, and unchanged levels of the antioxidant enzyme, superoxide dismutase-2, accompanied these impairments. $\mathbf{A} / \mathbf{T}$ mice featured deficient neurovascular and neurometabolic coupling to whisker stimulation, cholinergic denervation, cerebral and cerebrovascular $\mathbf{A} \beta$ deposition, astrocyte activation, and impaired Morris water maze performance, which gained severity with age. The combined A $\beta$ - and TGF- $\beta 1$-driven pathology recapitulates salient cerebrovascular, neuronal, and cognitive AD landmarks and yields a versatile model toward highly anticipated diagnostic and ther- apeutic tools for patients featuring $A \beta$ and TGF- $\beta 1$ increments. (Am J Pathol 2010, 177:3071-3080; DOI: 10.2353/ajpath.2010.100339)

Alzheimer's disease (AD) features neuronal and synaptic dysfunction, abnormal cerebral protein deposits, activated glia and progressive cognitive decline. ${ }^{1-3}$ AD patients also exhibit structural cerebrovascular alterations, ${ }^{4,5}$ and early deficits in resting and evoked cerebral glucose uptake and cerebral blood flow responses, which can undermine optimal brain function, and aggravate an ongoing pathogenic process. ${ }^{6-8}$ These changes have been linked to increased levels and deposition of amyloid- $\beta(A \beta)$ in brain parenchyma (senile plaques) and blood vessel walls (cerebral amyloid angiopathy; CAA), ${ }^{9,10}$ and to up-regulation of the profibrotic transforming growth factor- $\beta 1$ (TGF- $\beta 1$ ), perhaps a key molecular mediator of the $A D$ cerebrovascular pathology. ${ }^{11-15}$

Transgenic mice overproducing $A \beta$ and TGF- $\beta 1$ (A/T mice) were originally developed to study the possible modulatory role of TGF- $\beta 1$ on amyloid deposition. ${ }^{11,16}$ These early studies reported decreased plaque burden and accelerated vascular $A \beta$ accumulation in young and adult $A / T$ animals. ${ }^{11,16}$ More recently, reduced parenchymal and vascular $A \beta$ deposition was demonstrated when TGF- $\beta$ signaling was genetically blocked in old transgenic AD mice. ${ }^{17}$ Though contradictory, these studies collectively suggest that TGF- $\beta 1$ may regulate amyloid pathology in the $\mathrm{AD}$ brain, an idea supported by the correlation between

Supported by grant MOP-84275 from the Canadian Institutes of Health Research (E.H.); a grant from the Alzheimer Society of Canada (E.H.); a CIHR studentship (N.N.); fellowships from les Fonds de la Recherche en Santé du Québec and Jeanne Timmins Costello (B.O.); and a Heart and Stroke Foundation of Canada/Canadian Stroke Network fellowship (C.L.).

B.O. and N.N. contributed equally to this work.

Accepted for publication August 26, 2010.

Supplemental material for this article can be found on http://ajp. amjpathol.org.

Address reprint requests to Edith Hamel, Ph.D., Department of Neurology and Neurosurgery, Montreal Neurological Institute, McGill University, Montréal, QC, Canada H3A 2B4. E-mail: edith.hamel@mcgill.ca. 
TGF- $\beta 1$ mRNA levels and CAA scores in patients. ${ }^{11}$ Although the amyloid pathology has been partially characterized in $A / T$ animals, data are completely lacking on their cognitive and cholinergic status, functional cerebrovascular integrity, and evoked perfusion and metabolic responses to neuronal activation. Such results would aid in the validation of $A / T$ mice for the study of $A D$. It is therefore all the more surprising that this information is unavailable given the known detrimental cerebrovascular effects of $A \beta$ and TGF$\beta 1,{ }^{15,18-20}$ and the current interest in activity-driven brain hemodynamics and metabolism as clinical predictors or markers for $A D$ therapeutic efficacy.

We sought to characterize the progression of cerebrovascular and cognitive markers with age in $\mathrm{A} / \mathrm{T}$ mice. Particularly, we studied arterial reactivity and responsiveness to antioxidants in vitro, and investigated vascular proteins related to vasomotor function, oxidative stress and fibrosis. Additionally, we examined glial activation, amyloidosis, and indicators of neuronal/cognitive integrity, ie, the cholinergic innervation, the neuronally-driven cerebral blood flow and glucose uptake responses during whisker stimulation, and performance in the Morris water maze. Our novel findings highlight $A / T$ mice as a most suitable model in which to explore therapeutic strategies against cerebrovascular and neuronal alterations of $A D$ pathophysiology.

\section{Materials and Methods}

\section{AVT Transgenic Mice}

All experiments were in compliance with the Animal Ethics Committee of the Montreal Neurological Institute and the guidelines of the Canadian Council on Animal Care. $A / T$ animals were generated from the crossing of mice overexpressing mutated human amyloid precursor protein (APPSwe,Ind) driven by the platelet-derived growth factor $\beta$ promoter (APP mice, line $\mathrm{J} 20)^{21}$ and mice overexpressing constitutively active TGF- $\beta 1$ under the control of the glial fibrillary acidic protein (GFAP) promoter (TGF mice, line T64) ${ }^{22}$ on a C57BL/6J background. Approximately equal numbers of female and male heterozygous transgenic A/T mice and age-matched wild-type (WT) littermates were used at $6-8$ (young), $\sim 12$ (adult), and $\sim 18$ (old) months of age. Singly transgenic APP or TGF mice of the same ages, either littermates of the $A / T$ mice or from different cohorts, were used for comparisons with $A / T$ mice in some experiments, and were similarly prepared. Transgenes were detected with touchdown PCR on tail-extracted DNA. ${ }^{15}$ Mice were housed under a 12-hour light-dark cycle, in a room with controlled temperature $\left(23^{\circ} \mathrm{C}\right)$ and humidity (50\%), with food and tap water available ad libitum.

\section{Vascular and Brain Tissue Collection}

Mice were killed by cervical dislocation. Middle cerebral arteries were immediately tested in reactivity studies, while vessels of the circle of Willis and their branches, along with cortex and hippocampus were collected, snap-frozen and stored $\left(-80^{\circ} \mathrm{C}\right)$ for subsequent Western blot and enzyme-linked immunosorbent assay studies.
Separate mouse cohorts were perfused intracardially (4\% paraformaldehyde in $0.1 \mathrm{~mol} / \mathrm{L}$ phosphate-buffered saline, $\mathrm{pH}=7.4)$ under deep anesthesia $(65 \mathrm{mg} / \mathrm{kg}$ sodium pentobarbital, intraperitoneally), and brains postfixed overnight. Some hemibrains were cryoprotected, frozen in isopentane and stored $\left(-80^{\circ} \mathrm{C}\right)$ until cutting into $25-\mu \mathrm{m}$-thick free-floating coronal sections on a freezing microtome. Others were embedded in paraffin and cut 5 $\mu \mathrm{m}$ thick for use in immunohistochemistry.

\section{Vascular Reactivity}

Isolated, pressurized and submaximally preconstricted (serotonin, $2 \times 10^{-7} \mathrm{~mol} / \mathrm{L}$ ) middle cerebral artery segments were tested for dilatation to acetylcholine (ACh; $10^{-10}$ to $10^{-5} \mathrm{~mol} / \mathrm{L}$ ) or calcitonin gene-related peptide $\left(10^{-10}\right.$ to $\left.10^{-6} \mathrm{~mol} / \mathrm{L}\right)$ using on-line videomicroscopy. ${ }^{15}$ Constriction to endothelin- $1\left(10^{-10}\right.$ to $\left.10^{-6} \mathrm{~mol} / \mathrm{L}\right)$ or diameter decrease during nitric oxide (NO) synthase (NOS) inhibition with $\mathrm{N}^{\omega}$-nitro-L-arginine $\left(10^{-5} \mathrm{~mol} / \mathrm{L}\right.$; $35 \mathrm{~min}$ utes) were tested on vessels at basal tone. In some vessels, dilatation to ACh was tested before and after incubation (30-60 minutes) with the free radical scavenger superoxide dismutase (SOD; 120U/ml; Sigma, Oakville ON, Canada) or an inhibitor of NADPH oxidase (apocynin; $1 \mathrm{mmol} / \mathrm{L}$; Sigma), the main enzymatic source of superoxide $\left(\mathrm{O}_{2}^{--}\right)$in brain vessels of APP mice. ${ }^{20}$ Percent changes in vessel diameter from basal or preconstricted tone were plotted as a function of agonist concentration or time course of NOS inhibition. The maximal response and the concentration eliciting half of the maximal response $\left(\mathrm{EC}_{50}\right.$ value or $\left.\mathrm{pD}_{2}=-\left[\log \mathrm{EC}_{50}\right]\right)$ generated by GraphPad Prism software (version 4, San Diego, $\mathrm{CA}$ ) were used to evaluate agonist efficacy and potency, respectively.

\section{Western Blot}

Vessels were sonicated in Laemmli buffer for protein extraction, as described. ${ }^{15}$ Proteins $(12-15 \mu \mathrm{g})$ were separated by SDS-polyacrylamide gel electrophoresis and transferred to nitrocellulose membranes, which were incubated (1 hour) in TBST blocking buffer ( $50 \mathrm{mmol} / \mathrm{L}$ Tris- $\mathrm{HCl}, \mathrm{pH}=7.5,150 \mathrm{mmol} / \mathrm{L} \mathrm{NaCl}, 0.1 \%$ Tween 20) containing 5\% skim milk, then incubated overnight with either rabbit anti-SOD2 (1:2000; Stressgen, Ann Arbor, $\mathrm{MI}$ ), -connective tissue growth factor (1:300; Abcam, Cambridge, MA), -vascular endothelial growth factor (1:500; Santa Cruz Biotechnology, Santa Cruz, CA), -matrix metalloproteinase 9 (1:1000; Millipore, Temecula, CA) or mouse anti-endothelial NOS (1:500; BD Transduction Laboratories, San Jose, CA), -cyclooxygenase-2 (1:200; Santa Cruz Biotechnology), or $-\beta$-actin (1:10000; Sigma). Membranes were further incubated (2 hours) with horseradish peroxidase-conjugated secondary antibodies (1:2000; Jackson ImmunoResearch, West Grove, PA), and proteins visualized with enhanced chemiluminescence (ECL Plus kit; Amersham, ON, Mississauga, Canada) using a phosphor Imager (Scanner STORM 860; GE Health Care, Piscataway, 
$\mathrm{NJ}$ ), followed by densitometric quantification with ImageQuant 5.0 (Molecular Dynamics, Sunnyvale, CA).

\section{Enzyme-Linked Immunosorbent Assay Measurement of $A \beta$}

Levels of soluble and insoluble $A \beta_{1-40}$ and $A \beta_{1-42}$ were measured in hemicortices using an enzyme-linked immunosorbent assay (BioSource International, Camarillo, CA), as previously described in full, ${ }^{23}$ and results expressed as nanomoles per gram of protein in the supernatant or formic acid-soluble fraction.

\section{Histochemistry and Immunohistochemistry}

Dewaxed thin sections $(5 \mu \mathrm{m})$ were stained with $1 \%$ Sirius red ( $\sim 30$ minutes) to reveal total collagen in the pia and intracortical microvessels (MVs) or were pretreated with $1 \% \mathrm{H}_{2} \mathrm{O}_{2}$ (10 minutes) and incubated overnight at room temperature with goat anti-collagen I (1:300; Millipore), -choline acetyltransferase (ChAT; 1:250; Millipore) or mouse anti-A $\beta$ (6E10 targeting total $A \beta ; 1: 3000$; Covance, Emeryville, CA) followed by species-specific biotinylated IgG, the avidin-biotin complex, and the reaction visualized with $0.05 \%$ 3,3'-diaminobenzidine-nickel (Vector Laboratories, Burlingame, CA). ChAT immunostaining was tested only in adult and old $A / T$ mice when cholinergic innervation is preserved in TGF mice, ${ }^{24}$ but significantly reduced in singly transgenic APP mice. ${ }^{23,25}$ Freefloating thick sections were stained with $1 \%$ Thioflavin S (8 minutes) to reveal mature, dense core amyloid plaques or incubated with rabbit anti-GFAP (1:1000; DAKO, Mississauga, ON, Canada), followed by donkey anti-rabbit cyanin 2 (Cy2)-conjugated secondary antibody (1:400; Jackson ImmunoResearch) for the detection of activated astrocytes. Sections were observed under light microscopy or epifluorescence (Leitz Aristoplan microscope, Leica, Montréal, QC), and digital pictures acquired (Coolpix 4500; Nikon, Tokyo, Japan). Double immunodetection of activated astrocytes and $A \beta$ plaques was performed with simultaneous incubation of rabbit anti-GFAP and mouse 6E10, followed by donkey anti-rabbit Cy2- and anti-mouse Cy3-conjugated secondary antibodies.

\section{Staining Quantification}

Digital images (two or three sections/mouse, three to five mice/group) taken under the same conditions were analyzed with MetaMorph (6.1r3, Universal Imaging, Downingtown, PA). Collagen I and Sirius red staining intensities of the pia and intracortical MVs (four to 13 vessels/ mouse) were quantified in magnified images and expressed as an optical density ratio against the intensity of the adjacent parenchyma. The areas of interest (somatosensory/cingulate cortex, hippocampus) containing Thioflavin S- and GFAP-positive elements were manually outlined in low-power images, while high-power microscope images of layers II to IV of the somatosensory cortex were used for quantification of ChAT-immunoreactive fibers (cell bodies were excluded). The number and/or area occupied by Thioflavin S-positive plaques, GFAP-positive astrocytes, and ChAT-positive cholinergic fibers was quantified and expressed as number or surface area occupied in the delineated areas of interest.

\section{Morris Water Maze}

The ability of mice to learn and remember the location of a hidden platform located in a predefined (target) quadrant using visuospatial cues was tested for 5 consecutive days in a circular pool filled with water $\left(25^{\circ} \mathrm{C}\right.$, clouded with powdered skim milk), as previously described. ${ }^{23} \mathrm{At}$ least 2 hours after the last hidden platform trial on day 5 , mice were submitted to a 60-second probe trial (platform removed), followed by a cue trial (30 seconds) testing visual acuity and motivation, which required escape to a visible platform in at least one of two trials. Mice that failed to reach the visible platform were excluded from the analysis. Daily escape latencies to the hidden platform, as well as percent time spent and distance traveled in the target quadrant during the probe trial, along with swim speed, were measured with the 2020 Plus tracking system and Water 2020 software (Ganz FC62D video camera; HVS Image, Buckingham, UK). Animals were dried under a heating lamp after each trial, and all experiments were started at the same time every day.

\section{Laser Doppler Flowmetry}

In all age groups, laser Doppler flowmetry measurements of evoked cerebral blood flow (Transonic Systems Inc., Ithaca, NY) in response to sensory stimulation were carried out one week following the Morris water maze in anesthetized mice (ketamine, $80 \mathrm{mg} / \mathrm{kg}$ intraperitoneally; Wyeth, St-Laurent QC, Canada) fixed in a stereotaxic frame. ${ }^{23}$ Cerebral blood flow was recorded before, during and after whisker stimulation (20 seconds at $8-10$ $\mathrm{Hz}$ ), with four or five recordings acquired every 30 to 40 seconds and averaged per mouse. Cortical cerebral blood flow change was expressed as percent increase relative to baseline. The entire procedure was performed blind to the identity of the mouse.

\section{${ }^{18}$ F]Fluoro-2-Deoxy-D-Glucose-PET}

Eighteen-month-old $\mathrm{A} / \mathrm{T}$ mice and WT littermates were fasted overnight and scanned for cerebral uptake of $\left[{ }^{18} \mathrm{~F}\right]$ fluoro-2-deoxy-D-glucose induced by whisker stimulation (8-10 Hz, electric toothbrush, 45 minutes) under isoflurane sedation ( 1 to $2 \%$ in medical air) in a CTI Concorde R4 microPET scanner (Siemens Preclinical Solutions, Knoxville, TN), as previously described. ${ }^{23}$ Animals were kept warm with a heating lamp, while cardiac and respiration rate were maintained stable through online monitoring (Biopac Inc., Goleta, CA). Glycemia levels were measured before and after scans, and were similar in both WT and A/T groups (not shown). Functional metabolic images were reconstructed using a maximum a posteriori probability algorithm, and coregistered to re- 
spective high-resolution WT or A/T mouse structural MRI templates. MR images were acquired in separate groups of mice (WT, $n=5$ and $\mathrm{A} / \mathrm{T}, n=4$ ) with a $7 \mathrm{~T}$ Bruker Pharmascan system (Bruker Biospin, Ettlingen, Germany) using a 28-mm inner diameter quadrature volume resonator, and a 3D True FISP sequence with the following parameters: matrix size $=128 \times 128 \times 64$, field of view $=1.8 \mathrm{~cm} \times 1.8 \mathrm{~cm} \times 0.9 \mathrm{~cm}$, spatial resolution $=$ $140 \mu \mathrm{m} \times 140 \mu \mathrm{m} \times 140 \mu \mathrm{m}$, excitation flip angle $=30^{\circ}$, repetition time $=5.2 \mathrm{~ms}$, echo time $=2.6 \mathrm{~ms}$, number of excitations $=4$, number of phase cycles $=4$, total scan time $=35$ minutes. The images were reconstructed using a maximum intensity algorithm and the population averages generated using the approach described elsewhere. ${ }^{26}$ Regions of interest were drawn on the somatosensory cortices and the magnitude of activation expressed as the ratio of $\left[{ }^{18} \mathrm{~F}\right]$ fluoro-2-deoxy-D-glucose standard uptake value in the activated contralateral relative to the ipsilateral cortex. ${ }^{27}$ Final images represent the standard uptake value obtained by correcting individually for animal body weight and injected radioactivity dose.

\section{Statistical Analysis}

Data are means \pm SEM, and were compared by Student's $t$-test or one-way analysis of variance followed by Newman-Keuls posthoc tests. Morris water maze latency curves were analyzed by two-way analysis of variance followed by Bonferroni posthoc test, with day and genotype as factors. All statistical analyses were performed with GraphPad and $P<0.05$ was considered significant.

\section{Results}

\section{AVT Mice Develop an Early Progressive Decline of Cerebral Arterial Function}

Isolated middle cerebral arteries from young and adult $A / T$ mice displayed $\sim 50 \%$ loss of their ability to dilate to ACh and calcitonin gene-related peptide relative to vessels of age-matched WT littermates (Figure 1; Supplemental Table 1 at $h$ ttp://ajp.amjpathol.org). By 18 months of age, A/T mice further exhibited significantly impaired maximal diameter decrease during NOS inhibition with $N^{\omega}$-nitro-L-arginine, indicating a decline in constitutive endothelial NO synthesis that is crucial for establishing resting vessel tone. There was no contractile deficit to endothelin-1 in A/T arteries at any age (Figure 1; Supplemental Table 1 at http://ajp.amjpathol.org). The progressive deficits in arterial responsiveness could not be attributed to desensitization of cerebrovascular receptors, as agonist potencies $\left(\mathrm{pD}_{2}\right.$ values) were comparable between $W T$ and $A / T$ mice at all ages (Supplemental Table 1 at $h$ ttp://ajp.amjpathol.org). Cerebrovascular impairments of similar magnitude have been consistently measured in singly transgenic APP and TGF mice. Noteworthy was the lack of a synergistic $A \beta$ and TGF- $\beta 1$ effect in $A / T$ arteries, as evidenced in the qualitative comparison with reactivity data from APP and TGF arteries. (Supplemental Figure 1; Supplemental Table 1 at $h$ ttp:// ajp.amjpathol.org). ${ }^{15,23,24,28,29}$ This was particularly well illustrated in $A / T$ mice by their preserved contractile response to endothelin-1, in contrast to the deficit in TGF arteries; milder calcitonin gene-related peptide deficit relative to that in aged TGF animals; and later decline in $N^{\omega_{-}}$


Adult
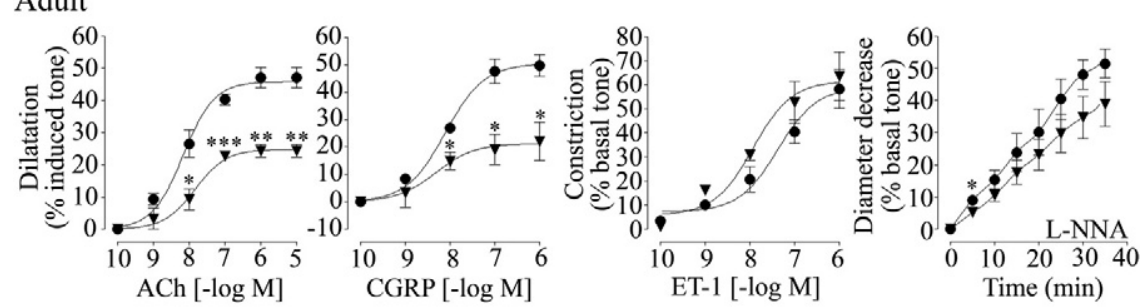

Old
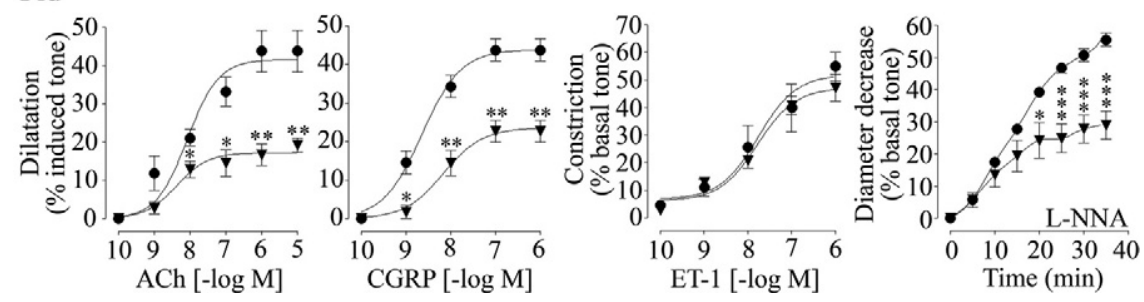

Figure 1. Age-related impairment in cerebrovascular reactivity in young ( $6-8$ months), adult ( $\sim 12$ months), and old ( $\sim 18$ months) $\mathrm{A} / \mathrm{T}$ mice (inverted triangles) relative to age-matched WT littermates (circles). Early dilatory deficits to ACh and calcitonin gene-related peptide (CGRP) in young and adult $\mathrm{A} / \mathrm{T}$ mice were accompanied by a late decline in constitutive NO synthesis in old $\mathrm{A} / \mathrm{T}$ animals, as seen with $N^{\omega}$-nitro-L-argininemediated inhibition of NOS (L-NNA, $10^{-5} \mathrm{~mol} /$ L). Constriction to endothelin-1 (ET-1) was preserved at all ages. Error bars represent SEM. Number of animals are indicated in Supplemental Table 1 at http://ajp.amjpathol.ong. Comparison to WT using Student's $t$-test. ${ }^{*} P<0.05,{ }^{* *} P<0.01,{ }^{* * * * *} P<0.001$. 
A

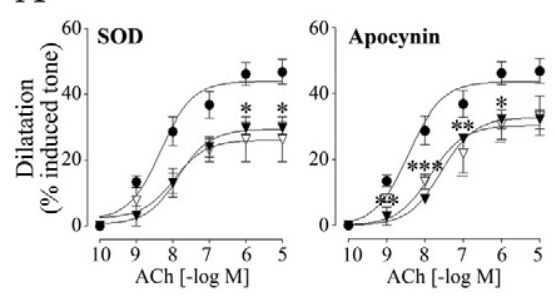

C

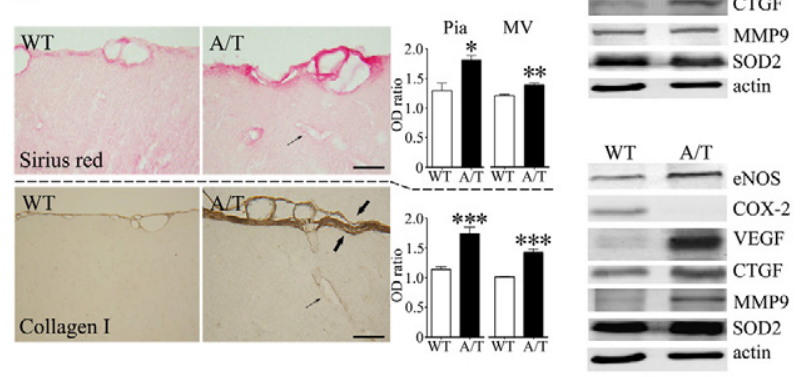

nitro-L-arginine response versus its early onset in the singly transgenic lines.

\section{A/T Mice Display Arterial Dysfunction Not Related to Oxidative Stress}

We sought to elucidate the mechanism of cerebrovascular impairment in aged $\mathrm{A} / \mathrm{T}$ mice by treating arteries with SOD or apocynin, which respectively scavenges $\mathrm{O}_{2}^{--}$and abrogates its production. Antioxidants have been shown to normalize cerebrovascular responses of APP, 15, 18,23,30 but not TGF mice, ${ }^{24}$ and we wished to determine whether free radicals accounted for the cerebrovascular dysfunction in the $A / T$ model. These in vitro antioxidant approaches were ineffective as they were unable to restore ACh-mediated dilatations (Figure 2A). Furthermore, no significant change was detected in $A / T$ vessels at any age in the levels of the antioxidant enzyme SOD2, which is induced by $\mathrm{O}_{2}^{--}$and can be used as an indicator of enhanced oxidative stress (Figure 2B). Instead, pial vessels from $A / T$ mice exhibited changes in enzymes synthesizing vasodilators, ie, reduced levels of cyclooxygenase-2 beginning as a trend in young, and becoming significant in adult and old mice, as well as significant up-regulation of endothelial NOS in young mice. A/T arteries also featured robust increases in levels of growth factors (vascular endothelial growth factor, connective tissue growth factor) involved in vascular fibrosis, starting in young and persisting in old mice. Arteries also exhibited late up-regulation of matrix metalloproteinase 9 , an enzyme involved in the breakdown of the extracellular matrix during vascular remodeling (Figure 2B). Furthermore, $A / T$ mice featured significant collagen accumulation in penetrating MVs and in the surface pial membrane, resulting in its greater thickness (Figure 2C). Sirius red staining intensity was markedly augmented in the pia (81\%) and MVs (39\%) compared to the adjacent paren-

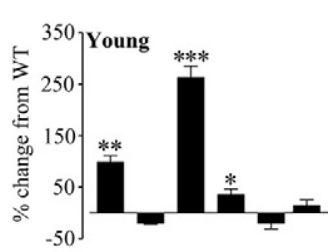

Figure 2. $\mathrm{A} / \mathrm{T}$ mouse vessels were characterized by resistance to antioxidants, alterations in vascular signaling molecules and cerebrovascular fibrosis. A: The impaired ACh-mediated dilatation of aged $\mathrm{A} / \mathrm{T}$ (inverted filled triangles) relative to WT mice (circles) was not improved in $\mathrm{A} / \mathrm{T}$ arteries after in vitro incubation (inverted open triangles) with the $\mathrm{O}_{2}^{--}$scavenger SOD or a blocker of its synthesis, apocynin ( $n=3-4$ mice/group). B: Disturbed levels of vasodilator-synthesizing enzymes, endothelial NOS eNOS and cyclooxygenase-2 (COX-2) and of markers related to vascular remodeling vascular endothelial growth factor (VEGF), connective tissue growth factor (CTGF), matrix metalloproteinase 9 (MMP-9) but not of the oxidative stress marker SOD2, as measured by Western blot in pial vessels of $\mathrm{A} / \mathrm{T}$ relative to WT mice. Actin was used to normalize loading variation $(n=3-6$ mice/group). C: Collagen accumulation in the pia (thick arrows) and intraparenchymal microvessels (MVs, thin arrows) of 18-month-old A/T relative to WT mice, measured as an optical density (OD) ratio of the vessel intensity to that of adjacent parenchyma in Sirius red-stained (top) and collagen I-immunoreactive (bottom) 5 - $\mu$ m-thick paraffin sections ( $n=3-9$ mice/group). Scale bar $=20$ $\mu \mathrm{m}$. Error bars represent SEM. ${ }^{*} P<0.05,{ }^{* * *} P<$ $0.01,{ }^{\text {**** }} P<0.001$ when compared with WT using Student's $t$-test or one-way analysis of variance followed by Newman-Keuls posthoc test.

chyma of 18 month-old $A / T$ mice, with substantially smaller increments in WT animals in these respective vascular beds (pia: 29\%, MVs: 21\%). Analogous collagen I increases were seen in the pia (74\%) and MVs (42\%) of $\mathrm{A} / \mathrm{T}$ mice (Figure 2C), which likely accounted for the increased rigidity of their vessels perceived during dissection, handling, and cannulation. In contrast, collagen I immunostaining was very weak in WT mice, being increased by $14 \%$ in the pia but barely detectable in MVs $(1 \%)$ relative to the parenchyma (Figure $2 \mathrm{C}$ ), confirming our previous report of collagen I up-regulation in the context of vascular pathology. ${ }^{15}$ Collectively, these data argue against oxidative stress as the main pathogenic mechanism of vascular dysfunction, and point to disturbances in enzymes and proteins underlying vascular structure and signaling. We cannot rule out that chronic in vivo antioxidant treatment might be effective. However, based on the recent failure of this approach in TGF mice featuring similar cerebrovascular fibrosis, vascular protein alterations, and in vitro resistance to antioxidants, ${ }^{24}$ we are inclined to consider alternate mechanisms of vascular dysfunction in $A / T$ mice, ones most likely shared with the TGF model.

\section{AVT Mice Exhibit AD-Like Neuropathological Changes}

$A / T$ mice exhibited an increase in levels of soluble and insoluble $A \beta_{1-40}$ and $A \beta_{1-42}$ between $6-8$ and 12 months, with further increases in levels of $A \beta_{1-40}$, but not of $A \beta_{1-42}$ at 18 months of age, as measured in the cortex by enzyme-linked immunosorbent assay (Figure 3A). They also displayed age-dependent $A \beta$ plaque deposition in the cortex and hippocampus, shown by a gradual increase in the number and surface area (plaque load) occupied by Thioflavin S-positive dense core plaques from young to adult animals (Figure 3B). Between 12 and 18 months, 
A

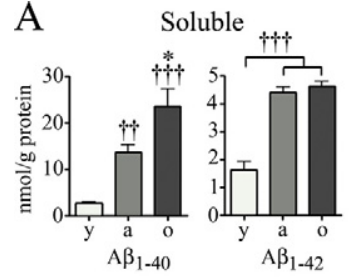

B

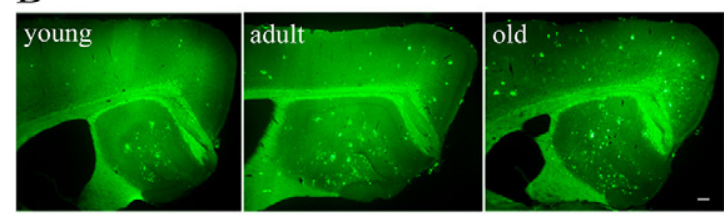

Cortex

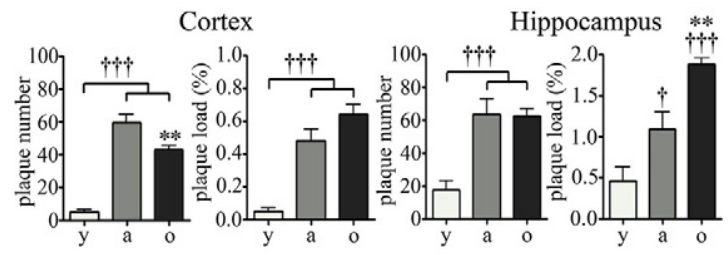

$\mathrm{C}$

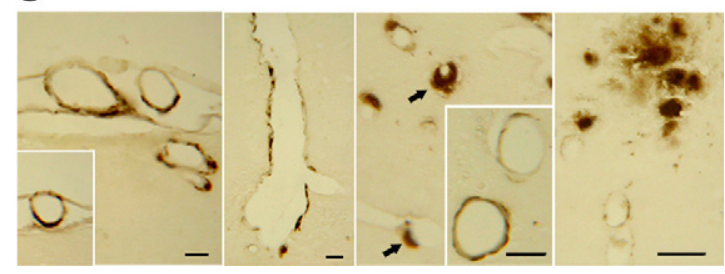

Figure 3. Progressive amyloidosis in $\mathrm{A} / \mathrm{T}$ mice. A: Levels of soluble and insoluble $\mathrm{A} \beta_{1-40}$ and $\mathrm{A} \beta_{1-42}$ increased as a function of age in $\mathrm{A} / \mathrm{T}$ mice, as assayed in hemicortices by enzyme-linked immunosorbent assay. B: Gradual increase in the number and load (percentage of surface area) of Thioflavin S-positive amyloid plaques in the cortex and hippocampus of $\mathrm{A} / \mathrm{T}$ mice. No such deposits were seen in WT animals (not shown). y, young; a, adult; o, old. C: Extensive CAA in the vasculature of aged A/T mice, as respectively seen from left to right, in surface pial vessels, a penetrating cortical artery, arterioles with associated extraluminal deposits (arrows) and hippocampal arteries (inset), and in hippocampal arterioles and capillaries, next to which parenchymal A $\beta$ plaques can be seen. Scale bars $=20 \mu \mathrm{m}$. Error bars represent SEM ( $n=4$ mice/group). ${ }^{\dagger} P<0.05,{ }^{\dagger} P<0.01,{ }^{\dagger t} P<0.001$ for comparison to young mice or ${ }^{*} P<0.05,{ }^{* *} P<0.01$ for comparison to adult mice using one-way analysis of variance followed by Newman-Keuls posthoc test.

plaque number reached a plateau in the hippocampus, or slightly decreased in the cortex, while plaque load continued to expand or stayed the same in these respective areas, indicating an increase in the size of certain plaques during this period. Together with the significant increments in soluble and insoluble $A \beta_{1-40}$ from 12 to 18 months, this finding suggests that existing $A \beta$ plaques may have acted as seeds for additional $A \beta_{1-40}$ deposition. In comparative experiments, we found a trend for diminished plaque load in young $A / T$ relative to APP mice, which became significant in adult and aged animals (Supplemental Figure 2 at http://ajp.amjpathol.org). This would support the argued modulatory effect of TGF- $\beta 1$ on amyloid deposition, and suggest a clearance phenomenon, as previously observed in young and old $\mathrm{A} / \mathrm{T}$ mice. ${ }^{11,16}$ Its occurrence later in our model may reflect the higher $A \beta$ levels of the J20 APP line ${ }^{21}$ used to generate $A / T$ mice, instead of the previously used J9. ${ }^{11,16}$ Finally, inspection of $A \beta$ immunoreactivity in thin sections
A
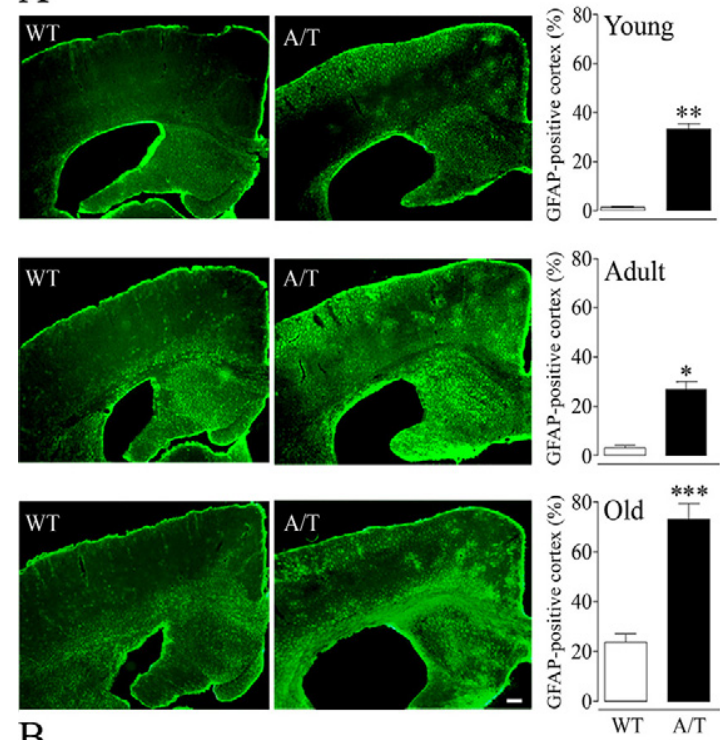

B

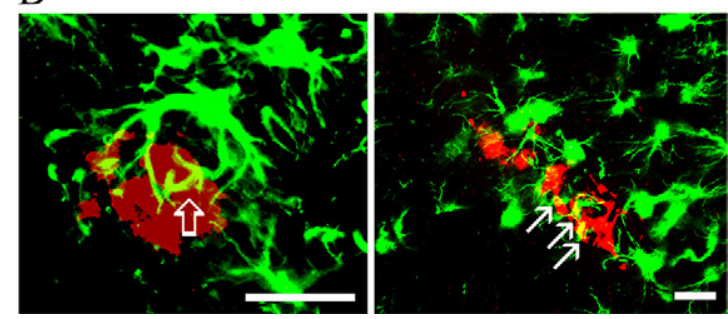

Figure 4. A: Enhanced astrocyte activation seen as clusters and diffuse GFAP-positive material in the brains of $\mathrm{A} / \mathrm{T}$ mice with a smaller age-related activation also detectable in WT littermates. Astrocyte activation was expressed as the percent cortical area occupied by GFAP-positive cells. Scale bar $=20 \mu \mathrm{m}$. B: Activated astrocytes (green) were found associated with A $\beta$ deposits (red) in the parenchyma (left) and with cerebral vessels (right). Note, in yellow, the contact points between astrocytic processes and an A $\beta$ plaque (thick open arrow) or an amyloid-laden vessel (CAA) (thin arrows $)(n=3-7 \mathrm{mice} /$ group $)$. Scale bars: left, $40 \mu \mathrm{m}$; right, $20 \mu \mathrm{m}$. Error bars represent SEM. ${ }^{*} P<0.05,{ }^{* * *} P<0.01,{ }^{* * * *} P<0.001$ when compared with WT using Student's $t$-test.

from 18-month-old $A / T$ mice revealed parenchymal $A \beta$ senile plaques and widespread CAA in pial, intracortical, and hippocampal brain vessels (Figure 3C), confirming previous reports in young and adult $A / T$ animals. ${ }^{11,16}$

In addition, $A / T$ mice displayed an inflammatory response characterized by activated GFAP-positive astrocytes. The GFAP-positive area in the cortex increased from young to old $A / T$ mice, with a smaller age-dependent activation in WT animals. Activated astrocytes in A/T mice distributed in clusters as well as diffusely throughout the cortex (Figure 4A), and surrounded $A \beta$ plaques and amyloid-laden vessels (Figure 4B). Interestingly, this pattern was reminiscent of both the cluster-like activation of APP mice ${ }^{23}$ and diffuse, perivascular astrocytosis of TGF mice. ${ }^{11,22,24}$

\section{Neuronal and Cognitive Impairments in A/T Mice}

Adult and aged $A / T$ mice featured a $\sim 22$ to $23 \%$ reduction $(P<0.05$ for both ages) in the number of cortical cholinergic fibers (Figure 5A). Further, $\left[{ }^{18} \mathrm{~F}\right]$ fluoro-2-de- 
A

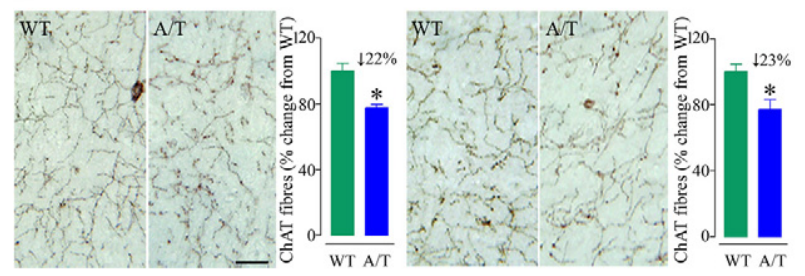

$\mathrm{B}$

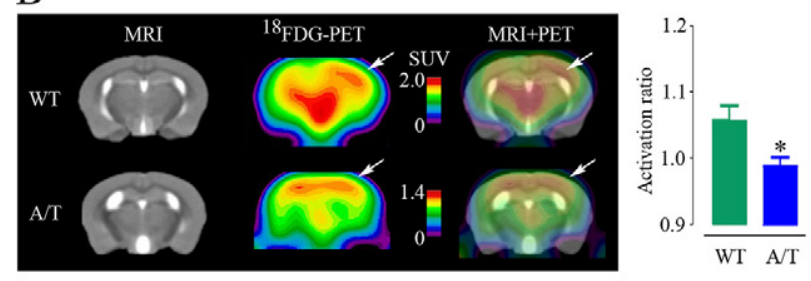

$\mathrm{C}$

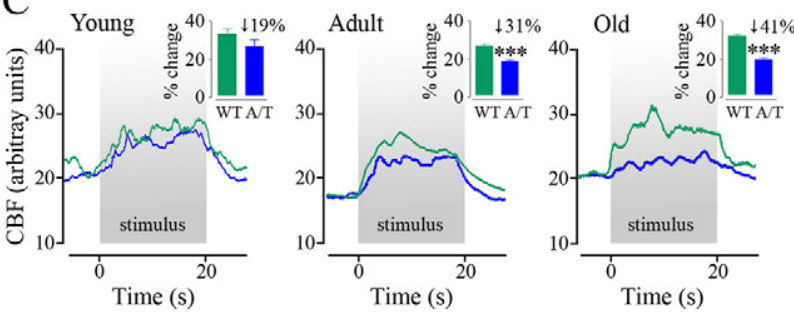

Figure 5. Neuronal dysfunction in A/T mice. A: Decline in the number of cortical cholinergic fibers in paraffin sections from adult (left) and old (right) $\mathrm{A} / \mathrm{T}$ mice, relative to WT littermates, as detected with ChAT immunohistochemistry. Scale bar $=20 \mu \mathrm{m}$. Values above histograms indicate the percentage of fiber loss compared to control animals. B: Decrease in the cerebral glucose uptake response to whisker stimulation in the somatosensory cortex (arrows) of 18-month-old A/T relative to WT mice ( $n=3-5$ mice/group). Standard uptake value (SUV) scales were adjusted to match the local activation spots in the two groups rather than the global brain uptake. The activation ratio is the corrected SUV in the activated contralateral relative to the ipsilateral somatosensory cortex. C: Gradual decline in the activitydriven hemodynamic response to whisker stimulation in $\mathrm{A} / \mathrm{T}$ mice (blue) compared to age-matched WT controls (green), as measured by laser Doppler flowmetry ( $n=4-5 \mathrm{mice} /$ group). Values above histograms indicate the percent loss of the response compared to control animals. Error bars represent SEM. Comparisons to WT, ${ }^{*} P<0.05,{ }^{* * * *} P<0.001$ using Student's $t$-test.

oxy-D-glucose-PET scans following whisker stimulation revealed a significant impairment of glucose uptake in the activated somatosensory cortex of aged $\mathrm{A} / \mathrm{T}$ animals (activation ratio A/T: $0.99 \pm 0.01$ versus WT: $1.06 \pm 0.02$, $P<0.05$ ) (Figure 5B) that may have derived from the observed alterations in vascular, astroglial and neuronal compartments. ${ }^{31}$ Moreover, there was a gradual loss of the neuronally-driven hemodynamic response to sensory stimulation, which was significant in adult $(-31 \%, P<$ 0.001 ) and progressively more severe in aged animals $(-41 \%, P<0.001)$ (Figure $5 \mathrm{C})$. The extent of the deficit compared well to that seen in APP mice, although it was more progressive (Supplemental Table 2 at http://ajp. amjpathol.org). Finally, $A / T$ mice showed increased latencies to locate the hidden platform in the Morris water maze at 6-8 months of age, whereas performance in the probe trial was lower but not significantly different from that of control mice, indicating a learning deficit but no clear memory impairment at this age. A significant deficit in probe trial performance emerged in 12-month-old and continued in 18-month-old A/T animals (Figure 6), which was not due to differences in swim speed, visual acuity,
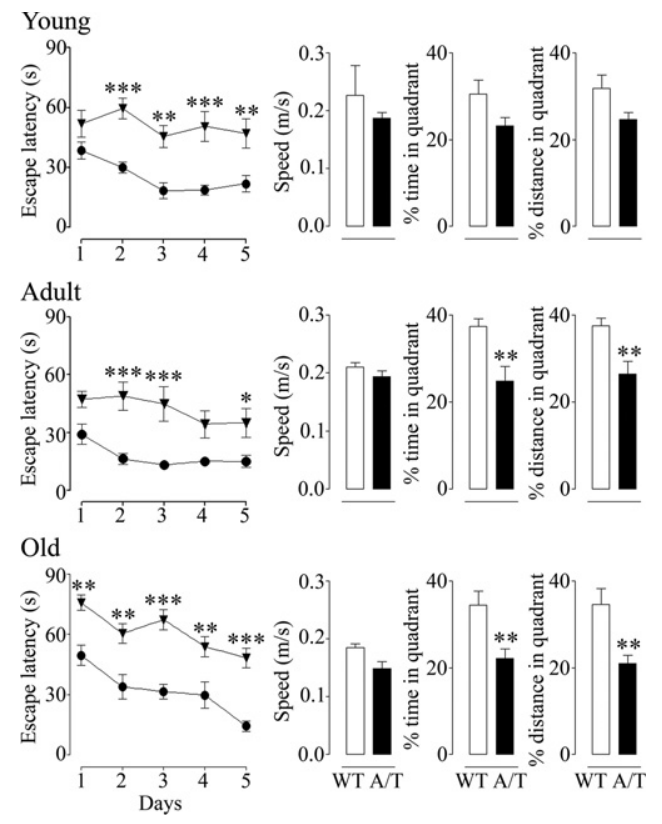

Figure 6. Progressive decline in Morris water maze performance in A/T mice (inverted triangles) compared to aged-matched WT counterparts (circles). Young mice featured impaired acquisition during hidden-platform testing, but only a trend toward decline in memory retention during the probe trial. Significant probe trial deficits appeared in adult and old A/T mice. Error bars represent SEM ( $n=8-16$ mice/group). Comparisons to WT, ${ }^{*} P<0.05,{ }^{* *} P<$ $0.01,{ }^{* * * *} P<0.001$ using two-way analysis of variance followed by Bonferroni posthoc test (latency curves) or using Student's $t$-test (probe trial histograms).

locomotor defects or lack of motivation, as demonstrated by successful escape onto the visible platform. Comparatively, APP mice showed deficits in both the learning and memory components of the test at all ages, as shown at 6 months, whereas TGF mice performed as well as WT mice in this task up to 18 months of age (Supplemental Figure 3 at http://ajp.amjpathol.org).

\section{Discussion}

Since the original development of transgenic mice overproducing both $A \beta$ and TGF- $\beta 1,{ }^{11,16}$ this is the first characterization of their cerebrovascular, neuronal and mnemonic integrity. More importantly, our study provides novel functional data on activity-induced changes in cerebral glucose uptake and cerebrovascular status that are in line with current research initiatives to develop markers for early diagnosis and treatment efficacy. As a result, the $A / T$ model may be used to better assess interactions between $A \beta$ and TGF- $\beta 1$ in $A D$, and to develop therapeutic strategies that can rescue both cerebrovascular and mnemonic hallmarks of AD pathophysiology.

\section{AD-Like Cerebrovascular Pathology in AVT Mice and Therapeutic Implications}

An appealing characteristic of $A / T$ mice is the development of a functional and structural cerebrovascular pathology, simultaneously triggered by soluble $A \beta$, TGF- $\beta 1$, CAA, and basement membrane thickening, as seen in human $A D .4,5,32,33$ The interaction between vascular fi- 
brosis and CAA is of interest, as matrix proteins such as collagen and perlecan accumulating in $A D$ basement membranes ${ }^{33}$ have the ability to bind $A \beta$ and enhance its fibrillogenesis. ${ }^{34} \mathrm{CAA}$ may thus result from the enhanced capacity of thickened vessels to amass $A \beta$. This would agree with the ability of TGF- $\beta 1$ to prompt vascular $A \beta$ deposition when overexpressed in the brains of young APP mice (2 to 3 months), as CAA was not seen in singly transgenic APP animals of equivalent age. ${ }^{11}$ It is also in line with the reported correlation between TGF- $\beta 1$ mRNA levels and CAA scores in AD brains. ${ }^{11}$ CAA may additionally result from vascular wall alterations that hinder vessel pulsations believed to drive $A \beta$ clearance along the perivascular drainage route within arterial and arteriolar basement membranes. ${ }^{35}$ Such a scenario is supported by the perivascular accumulation of $A \beta$ seen here in concentric circles around some A/T brain vessels (Figure $3 C$ ). A/T mice thus offer the opportunity to test whether strategies that can reverse or attenuate excessive matrix protein accumulation and vascular stiffness will diminish CAA. Used in conjunction with $A \beta$ immunotherapy, these could help counter the transient increase in CAA and risk of cerebral microhemorrhages reported with vaccination in AD models ${ }^{36}$ and human trials. ${ }^{37}$ In addition, attenuating CAA could improve the function of astrocytes, key intermediaries in neurovascular coupling. ${ }^{38}$ CAA can induce loss of the water channel aquaporin 4 and of various potassium channel subtypes in astrocytic end-feet ${ }^{39}$ that, combined with the progressive astrocyte activation measured here, could have contributed to the age-related impairment of perfusion responses. Normalizing CAA could thus ameliorate glial function and perfusion.

Therapies against the deleterious vasoactive properties of soluble $A \beta$ would be most useful. ${ }^{40}$ Indeed, the peptide potently deregulates vascular function, even in young APP mice devoid of CAA, by activating vascular $\mathrm{NADPH}$ oxidase and $\mathrm{O}_{2}^{-}$synthesis, which results in the sequestration of vasodilators and free radical damage to vascular enzymes and receptors. ${ }^{15,18,20,30}$ These dysfunctions are promptly reversed by antioxidants in vitro and in vivo, even in arteries from aged APP mice. ${ }^{15,23,41} \mathrm{~A}$ caveat to pure antioxidant therapy is warranted by its inefficacy when applied to fibrotic TGF arteries, ${ }^{15}$ and here, to $A / T$ arteries. Both the $\mathrm{O}_{2}^{--}$scavenger SOD, and NADPH oxidase inhibitor, apocynin, were unable to restore ACh-mediated dilatations. Though chronic in vivo antioxidant treatment would be ultimately conclusive, it was ineffective in TGF mice, ${ }^{24}$ suggesting that a combined approach with compounds targeting structural alterations or vasodilatory signaling pathways should be favored.

The relevance of the $A / T$ model for the study of altered brain hemodynamics in $A D$ is strengthened not only by reports of TGF- $\beta 1$ up-regulation in the brain and vasculature of $A D$ patients, ${ }^{11-14,42}$ but also in elderly individuals who have suffered a stroke ${ }^{43}$ and in subjects with hypertension and diabetes, ${ }^{44}$ conditions that acutely or chronically limit cerebral blood flow and increase the risk for developing $A D,{ }^{6,45}$ especially if they co-occur in the same individual. ${ }^{46}$ In at-risk patients, TGF- $\beta 1$ could con- ceivably regulate $A \beta$ production directly. This is suggested by the presence of a TGF- $\beta 1$-responsive element in the APP promoter and TGF- $\beta 1$-stimulated release of endogenous $A \beta_{1-40 / 42}$ peptides by cultured human astrocytes. ${ }^{47}$ Alternatively, TGF- $\beta 1$ production may be triggered by $A \beta,{ }^{48}$ or both peptides may be up-regulated concomitantly in neurons, glia, and vascular cells by acute ischemic events or chronic cerebrovascular insufficiency. ${ }^{49,50}$ In $A / T$ mice, $A \beta$ and TGF- $\beta 1$ are overproduced from birth and throughout the lifespan, and it seems that their interaction is responsible for the progressive hemodynamic deficit of $A / T$ animals. This deficit appears later than in APP or TGF mice, and surpasses that of TGF animals but reaches that of APP mice (Supplemental Table 2 at $h$ ttp://ajp.amjpathol.org ${ }^{24,29}$ ). In all, this emphasizes the usefulness of the $A / T$ model as a platform for pursuing strategies aimed at counteracting impaired brain hemodynamics that could promote or result from $A \beta$ and TGF- $\beta 1$ elevations.

\section{Contribution of $A \beta$ versus TGF- $\beta 1$ to the Neuronal and Cognitive Status of AVT Mice}

The cholinergic, metabolic and cognitive deficits of $A / T$ mice reflect mainly an $A \beta$-driven process, as they are not exhibited by singly transgenic TGF mice, ${ }^{24}$ and the deficit severity matches that of APP mice. ${ }^{23,25,28}$ Namely, the loss of cortical ChAT-positive fibers, a landmark of $A D^{51}$ reproduced in APP mouse models ${ }^{25,52-54}$ but not in TGF mice, ${ }^{24}$ has been attributed to the cholinotoxic effects of soluble $A \beta{ }^{55}$ It seems unrelated to $A \beta$ deposition, since no relationship could be established between the presence and location of $A \beta$ plaques and denervation severity. ${ }^{25}$ However, despite the increase in soluble $A \beta$ oligomers from adult to old $A / T$ mice, the cholinergic denervation did not gain in severity with aging. This stabilization could result from a TGF- $\beta 1$ protective effect on neurons. In support of such a role is the delayed probe trial deficit in 12-month-old $A / T$ mice relative to its earlier onset in 6-month-old APP animals, known for their early synaptic and cognitive dysfunction. ${ }^{56,57}$ TGF- $\beta 1$-mediated neuroprotection has been suggested during ischemic and $A \beta$ injuries ${ }^{48,50,58}$ through the regulation of proand antiapoptotic proteins or factors that counter the effects of $A \beta$, such as collagen VI. ${ }^{48,58,59}$ However, evidence for a TGF- $\beta 1$ neurodegenerative action has also been presented. ${ }^{17,60}$ Further, neuronal malfunction was apparent in $\mathrm{A} / \mathrm{T}$ mice, in the form of impaired stimulusevoked cerebral glucose uptake and eventual spatial memory decline. Moreover, given the detrimental cerebrovascular effects of TGF- $\beta 1,{ }^{15,19,24,29,61}$ alternative neuroprotective approaches should be considered. For example, therapies aimed at the cellular and molecular underpinnings of the impaired metabolic response may hold promise. These include key glycolytic enzymes or neuronal (GLUT3) and vascular/astrocytic (GLUT1) glucose transporters that are reduced in AD. ${ }^{62}$ 


\section{Conclusion}

The present study highlighted the progressive circulatory and neuronal deficits resulting from $A \beta$ and TGF- $\beta 1$ cooverproduction. As both elements coexist and interact in the $A D$ brain, and altered brain hemodynamics are receiving renewed attention in $A D$ pathogenesis, the current study provides new data on a unique mouse model with which to test strategies aimed at rescuing disrupted neuronal, glial, and vascular networks.

\section{Acknowledgments}

We thank Dr. Lennart Mucke (Gladstone Institute of Neurological Disease and Department of Neurology, UCSF, CA) and the J. David Gladstone Institutes for the hAPP swe Ind and TGF- $\beta 1$ transgenic mouse breeders, Ms. Priscilla Fernandes for the laser Doppler flowmetry experiments, Mr. Antonio Aliaga for performing the PET scans, and Mr. Jason Cakiroglu and Dr. Barry Bedell (Small Animal Imaging Laboratory, SAIL, Montreal Neurological Institute) for the MRI templates.

\section{References}

1. de la Torre JC: Is Alzheimer's disease a neurodegenerative or a vascular disorder? Data, dogma, and dialectics. Lancet Neurol 2004 , 3:184-190

2. Zlokovic BV: Neurovascular mechanisms of Alzheimer's neurodegeneration. Trends Neurosci 2005, 28:202-208

3. Kalaria RN, Maestre GE, Arizaga R, Friedland RP, Galasko D, Hall K, Luchsinger JA, Ogunniyi A, Perry EK, Potocnik F, Prince M, Stewart R, Wimo A, Zhang ZX, Antuono P: Alzheimer's disease and vascular dementia in developing countries: prevalence, management, and risk factors. Lancet Neurol 2008, 7:812-826

4. Mancardi GL, Perdelli F, Rivano C, Leonardi A, Bugiani O: Thickening of the basement membrane of cortical capillaries in Alzheimer's disease. Acta Neuropathol 1980, 49:79-83

5. Perlmutter LS, Chui HC: Microangiopathy, the vascular basement membrane and Alzheimer's disease: a review. Brain Res Bull 1990 24:677-686

6. Iadecola C: Neurovascular regulation in the normal brain and in Alzheimer's disease. Nat Neurosci Rev 2004, 5:347-360

7. Sun X, He G, Qing H, Zhou W, Dobie F, Cai F, Staufenbiel M, Huang LE, Song W: Hypoxia facilitates Alzheimer's disease pathogenesis by up-regulating BACE1 gene expression. Proc Natl Acad Sci USA 2006, 103:18727-18732

8. Langbaum JB, Chen K, Lee W, Reschke C, Bandy D, Fleisher AS, Alexander GE, Foster NL, Weiner MW, Koeppe RA, Jagust WJ, Reiman EM: Alzheimer's Disease Neuroimaging Initiative. Categorical and correlational analyses of baseline fluorodeoxyglucose positron emission tomography images from the Alzheimer's Disease Neuroimaging Initiative (ADNI) Neuroimage 2009, 45:1107-1116

9. Vinters HV, Wang ZZ, Secor DL: Brain parenchymal and microvascular amyloid in Alzheimer's disease. Brain Pathol 1996, 6:179-195

10. Roher AE, Kuo YM, Esh C, Knebel C, Weiss N, Kalback W, Luehrs DC, Childress JL, Beach TG, Weller RO, Kokjohn TA: Cortical and leptomeningeal cerebrovascular amyloid and white matter pathology in Alzheimer's disease. Mol Med 2003, 9:112-122

11. Wyss-Coray T, Masliah E, Mallory M, McConlogue L, Johnson-Wood $\mathrm{K}$, Lin C, Mucke L: Amyloidogenic role of cytokine TGF- $\beta 1$ in transgenic mice and in Alzheimer's disease. Nature 1997, 389:603-606

12. Wyss-Coray T, Lin C, Sanan DA, Mucke L, Masliah E: Chronic overproduction of transforming growth factor-beta1 by astrocytes promotes Alzheimer's disease-like microvascular degeneration in transgenic mice. Am J Pathol 2000, 156:139-150

13. Grammas $P$, Ovase R: Cerebrovascular transforming growth factor- $\beta$ contributes to inflammation in the Alzheimer's disease brain. Am $J$ Pathol 2002, 160:1583-1587

14. Tarkowski E, Issa R, Sjögren M, Wallin A, Blennow K, Tarkowski A, Kumar P: Increased intrathecal levels of the angiogenic factors VEGF and TGF-beta in Alzheimer's disease and vascular dementia. Neurobiol Aging 2002, 23:237-243

15. Tong XK, Nicolakakis N, Kocharyan A, Hamel E: Vascular remodeling versus amyloid $\beta$-induced oxidative stress in the cerebrovascular dysfunctions associated with Alzheimer's disease. J Neurosci 2005, 25:11165-11174

16. Wyss-Coray T, Lin C, Yan F, Yu GQ, Rohde M, McConlogue L, Masliah E, Mucke L: TGF-beta1 promotes microglial amyloid-beta clearance and reduces plaque burden in transgenic mice. Nat Med 2001, 7:612-618

17. Town T, Laouar Y, Pittenger C, Mori T, Szekely CA, Tan J, Duman RS, Flavell RA: Blocking TGF- $\beta$-Smad2/3 innate immune signaling mitigates Alzheimer-like pathology. Nat Med 2008, 14:681-687

18. Iadecola C, Zhang F, Niwa K, Eckman C, Turner SK, Fischer E, Younkin S, Borchelt DR, Hsiao KK, Carlson GA: SOD1 rescues cerebral endothelial dysfunction in mice overexpressing amyloid precursor protein. Nat Neurosci 1999, 2:157-161

19. Gaertner RF, Wyss-Coray T, Von Euw D, Lesné S, Vivien D, Lacombe $P$ : Reduced brain tissue perfusion in TGF- $\beta 1$ transgenic mice showing Alzheimer's disease-like cerebrovascular abnormalities. Neurobiol Dis 2005, 19:38-46

20. Park L, Anrather J, Zhou P, Frys K, Pitstick R, Younkin S, Carlson GA, ladecola $\mathrm{C}$ : NADPH-oxidase-derived reactive oxygen species mediate the cerebrovascular dysfunction induced by the amyloid beta peptide. J Neurosci 2005, 25:1769-1777

21. Mucke L, Masliah E, Yu GQ, Mallory M, Rockenstein EM, Tatsuno G Hu K, Kholodenko D, Johnson-Wood K, McConlogue L: High-level neuronal expression of $A \beta 1-42$ in wild-type human amyloid protein precursor transgenic mice: synaptotoxicity without plaque formation. J Neurosci 2000, 20:4050-4058

22. Wyss-Coray T, Feng L, Masliah E, Ruppe MD, Lee HS, Toggas SM, Rockenstein EM, Mucke L: Increased central nervous system production of extracellular matrix components and development of hydrocephalus in transgenic mice overexpressing transforming growth factor-beta 1. Am J Pathol 1995, 147:53-67

23. Nicolakakis N, Aboulkassim T, Ongali B, Lecrux C, Fernandes $P$ Rosa-Neto P, Tong XK, Hamel E: Complete rescue of cerebrovascular function in aged Alzheimer's disease transgenic mice by antioxidants and pioglitazone, a peroxisome proliferator-activated receptor gamma agonist. J Neurosci 2008, 28:9287-9296

24. Nicolakakis N, Aboulkassim T, Aliaga A, Tong XK, Rosa-Neto P, Hamel E: Intact memory in TGF- $\beta 1$ transgenic mice featuring chronic cerebrovascular deficit: recovery with pioglitazone. J Cereb Blood Flow Metab doi: 10.1038/jcbfm.2010.78

25. Aucoin JS, Jiang P, Aznavour N, Tong XK, Buttini M, Descarries L, Hamel E: Selective cholinergic denervation, independent from oxidative stress, in a mouse model of Alzheimer's disease. Neurosci 2005, 132:73-86

26. Lau JC, Lerch JP, Sled JG, Henkelman RM, Evans AC, Bedell BJ: Longitudinal neuroanatomical changes determined by deformationbased morphometry in a mouse model of Alzheimer's disease. Neurolmage 2008, 42:19-27

27. Kornblum HI, Araujo DM, Annala AJ, Tatsukawa KJ, Phelps ME, Cherry SR: In vivo imaging of neuronal activation and plasticity in the rat brain by high resolution positron emission tomography (microPET). Nature Biotechnol 2000, 18:655-660

28. Tong XK, Nicolakakis N, Fernandes P, Ongali B, Brouillette J, Quirion R, Hamel E: Simvastatin improves cerebrovascular function and counters soluble amyloid-beta, inflammation and oxidative stress in aged APP mice. Neurobiol Dis 2009, 35:406-414

29. Papadopoulos $P$, Ongali B, Hamel E: Selective in vivo antagonism of endothelin receptors in transforming growth factor- $\beta 1$ transgenic mice that mimic the vascular pathology of Alzheimer's disease. Can J Physiol Pharmacol 2010, 88:652-660

30. Park L, Zhou P, Pitstick R, Capone C, Anrather J, Norris EH, Younkin L, Younkin S, Carlson G, McEwen BS, ladecola C: Nox2-derived radicals contribute to neurovascular and behavioral dysfunction in mice overexpressing the amyloid precursor protein. Proc Natl Acad Sci USA 2008, 105:1347-1352

31. Pellerin L, Bouzier-Sore AK, Aubert A, Serres S, Merle M, Costalat R, 
Magistretti PJ: Activity-dependent regulation of energy metabolism by astrocytes: an update. Glia 2007, 55:1251-1262

32. Roher AE, Lowenson JD, Clarke S, Woods AS, Cotter RJ, Gowing E, Ball $\mathrm{MJ}$ : $\beta$-Amyloid-(1-42) is a major component of cerebrovascular amyloid deposits: implications for the pathology of Alzheimer disease. Proc Natl Acad Sci USA 1993, 90:10836-10840

33. Kalaria RN, Pax AB: Increased collagen content of cerebral microvessels in Alzheimer's disease. Brain Res 1995, 705:349-352

34. Castillo GM, Ngo C, Cummings J, Wight TN, Snow AD: Perlecan binds to the $\beta$-amyloid proteins ( $A \beta$ ) of Alzheimer's disease, accelerates $A \beta$ fibril formation, and maintains $A \beta$ fibril stability. J Neurochem 1997, 69:2452-2465

35. Weller RO, Subash M, Preston SD, Mazanti I, Carare RO: Perivascular drainage of amyloid- $\beta$ peptides from the brain and its failure in cerebral amyloid angiopathy and Alzheimer's disease. Brain Pathol 2008, 18:253-266

36. Wilcock DM, Gharkholonarehe N, Van Nostrand WE, Davis J, Vitek MP, Colton CA: Amyloid reduction by amyloid- $\beta$ vaccination also reduces mouse tau pathology and protects from neuron loss in two mouse models of Alzheimer's disease. J Neurosci 2009, 29: 79577965 Erratum in. J Neurosci 2010, 30:1197-1198

37. Boche D, Zotova E, Weller RO, Love S, Neal JW, Pickering RM, Wilkinson D, Holmes C, Nicoll JA: Consequence of A $\beta$ immunization on the vasculature of human Alzheimer's disease brain. Brain 2008, 131:3299-3310

38. Haydon PG, Carmignoto G: Astrocyte control of synaptic transmission and neurovascular coupling. Physiol Rev 2006, 86:1009-1031

39. Wilcock DM, Vitek MP, Colton CA: Vascular amyloid alters astrocytic water and potassium channels in mouse models and humans with Alzheimer's disease. Neuroscience 2009, 159:1055-1069

40. Han BH, Zhou ML, Abousaleh F, Brendza RP, Dietrich HH, Koenigsknecht-Talboo J, Cirrito JR, Milner E, Holtzman DM, Zipfel GJ: Cerebrovascular dysfunction in amyloid precursor protein transgenic mice: contribution of soluble and insoluble amyloid- $\beta$ peptide, partial restoration via $\gamma$-secretase inhibition. J Neurosci 2008, 28:13542-13550

41. Hamel E, Nicolakakis N, Aboulkassim T, Ongali B, Tong XK: Oxidative stress and cerebrovascular dysfunction in mouse models of Alzheimer's disease. Exp Physiol 2008, 93:116-120

42. Luterman JD, Haroutunian V, Yemul S, Ho L, Purohit D, Aisen PS, Mohs R, Pasinetti GM: Cytokine gene expression as a function of the clinical progression of Alzheimer disease dementia. Arch Neurol 2000, 57:1153-1160

43. Krupinski J, Kumar P, Kumar S, Kaluza J: Increased expression of TGF- $\beta 1$ in brain tissue after ischemic stroke in humans. Stroke 1996, 27:852-857

44. Peterson MC: Circulating transforming growth factor $\beta$-1: a partial molecular explanation for associations between hypertension, diabetes, obesity, smoking and human disease involving fibrosis. Med Sci Monit 2005, 11:RA229-RA232

45. Kalaria RN: The role of cerebral ischemia in Alzheimer's disease. Neurobiol Aging 2000, 21:321-330

46. Luchsinger JA, Reitz C, Honig LS, Tang M-X, Shea S, Mayeux R: Aggregation of vascular risk factors and risk of incident Alzheimer disease. Neurology 2005, 65:545-551

47. Lesné S, Docagne F, Gabriel C, Liot G, Lahiri DK, Buée L, Plawinski L, Delacourte A, Mackenzie ET, Buisson A, Vivien D: Transforming growth factor- $\beta 1$ potentiates amyloid- $\beta$ generation in astrocytes and in transgenic mice. J Biol Chem 2003, 278:18408-18418
48. Cheng JS, Dubal DB, Kim DH, Legleiter J, Cheng IH, Yu GQ, Tesseur I, Wyss-Coray T, Bonaldo P, Mucke L: Collagen VI protects neurons against $A \beta$ toxicity. Nat Neurosci 2009, 12:119-121

49. Bennett SAL, Pappas BA, Stevens WD, Davidson CM, Fortin T, Chen J: Cleavage of amyloid precursor protein elicited by chronic cerebral hypoperfusion. Neurobiol Aging 2000, 21:207-214

50. Dhandapani KM, Brann DW: Transforming growth factor- $\beta$ : a neuroprotective factor in cerebral ischemia. Cell Biochem Biophys 2003, 39:13-22

51. Geula C, Mesulam MM: Cortical cholinergic fibers in aging and Alzheimer's disease: a morphometric study. Neuroscience 1989, 33:469-481

52. Wong TP, Debeir T, Duff K, Cuello AC: Reorganization of cholinergic terminals in the cerebral cortex and hippocampus in transgenic mice carrying mutated presenilin-1 and amyloid precursor protein transgenes. J Neurosci 1999, 19:2706-2716

53. Jaffar S, Counts SE, Ma SY, Dadko E, Gordon MN, Morgan D, Mufson EJ: Neuropathology of mice carrying mutant APP(swe) and/or PS1 (M146L) transgenes: alterations in the p75(NTR) cholinergic basal forebrain septohippocampal pathway. Exp Neurol 2001, 170:227-243

54. Klingner M, Apelt J, Kumar A, Sorger D, Sabri O, Steinbach J, Scheunemann M, Schliebs R: Alterations in cholinergic and noncholinergic neurotransmitter receptor densities in transgenic Tg2576 mouse brain with beta-amyloid plaque pathology. Int J Dev Neurosci 2003, 21:357-369

55. Auld DS, Kornecook TJ, Bastianetto S, Quirion R: Alzheimer's disease and the basal forebrain cholinergic system: relations to beta-amyloid peptides, cognition, and treatment strategies. Prog Neurobiol 2002, 68:209-245

56. Hsia AY, Masliah E, McConlogue L, Yu GQ, Tatsuno G, Hu K, Kholodenko D, Malenka RC, Nicoll RA, Mucke L: Plaque-independent disruption of neural circuits in Alzheimer's disease mouse models. Proc Natl Acad Sci USA 1999, 96:3228-3233

57. Palop JJ, Jones B, Kekonius L, Chin J, Yu GQ, Raber J, Masliah E, Mucke L: Neuronal depletion of calcium-dependent proteins in the dentate gyrus is tightly linked to Alzheimer's disease-related cognitive deficits. Proc Natl Acad Sci USA 2003, 100:9572-9577

58. Caraci F, Battaglia G, Busceti C, Biagioni F, Mastroiacovo F, Bosco P, Drago F, Nicoletti F, Sortino MA, Copani A: TGF- $\beta 1$ protects against $\mathrm{A} \beta$-neurotoxicity via the phosphatidylinositol-3-kinase pathway. Neurobiol Dis 2008, 30:234-242

59. Tesseur I, Zou K, Esposito L, Bard F, Berber E, Can JV, Lin AH, Crews L, Tremblay P, Mathews P, Mucke L, Masliah E, Wyss-Coray T: Deficiency in neuronal TGF-beta signaling promotes neurodegeneration and Alzheimer's pathology. J Clin Invest 2006, 116:3060-3069

60. Salins P, He Y, Olson K, Glazner G, Kashour T, Amara F: TGF-beta1 is increased in a transgenic mouse model of familial Alzheimer's disease and causes neuronal apoptosis. Neurosci Lett 2008, 430:81-86

61. Tong XK, Hamel E: Transforming growth factor-beta 1 impairs endothelin-1-mediated contraction of brain vessels by inducing mitogenactivated protein (MAP) kinase phosphatase-1 and inhibiting p38 MAP kinase. Mol Pharmacol 2007, 72:1476-1483

62. Simpson IA, Chundu KR, Davies-Hill T, Honer WG, Davies P: Decreased concentrations of GLUT1 and GLUT3 glucose transporters in the brains of patients with Alzheimer's disease. Ann Neurol 1994, 35:546-551 